\title{
Bioavailability of Commercial Preparations of Oxolinic Acid Administered to Chickens under Fasting and Non-fasting Conditions and its Relation to their In Vitro Dissolution Rates
}

\author{
Koko HAMAMOTO and Hiroyasu OGATA ${ }^{1)}$ \\ National Veterinary Assay Laboratory, Tokura 1-15-1, Kokubunji, Tokyo 185, and ${ }^{1)}$ Department of Biopharmaceu- \\ tics, Meiji College of Pharmacy, Tanashi, Tokyo 188, Japan
}

(Received 26 June 1987/Accepted 16 July 1988)

\begin{abstract}
The bioavailability of oxolinic acid (OA) in three different preparations (A; suspension, B and $\mathrm{C}$; commercial powders) with different mean particle sizes of $\mathrm{OA}(\mathrm{A} ; 1 \mu \mathrm{m}, \mathrm{B} ; 5 \mu \mathrm{m}, \mathrm{C} ; 20 \mu \mathrm{m})$ was studied after oral administration to chickens $(20 \mathrm{mg} / \mathrm{kg})$. Effect of administration conditions, fasting and non-fasting, was also studied. The dissolution rates of the preparations showed large differences according to differences in mean particle size. Under fasting conditions, significant differences in extents of bioavailability were found among the preparations, although the bioavailabilities of preparations A and B were almost the same. The bioavailabilities of OA from preparations $\mathrm{B}$ and $\mathrm{C}$ were enhanced after oral administration, and the differences in bioavailability between the preparations became also greater under non-fasting conditions. From the results, it is suggested that the bioavailability of OA of which mean particle size is more than $5 \mu \mathrm{m}$ depends on the dissolution rate, but not of which less than $5 \mu \mathrm{m}$.-KEY wORDS: bioavailability chicken, dissolution rate, mean particle size, oxolinic acid.
\end{abstract}

Jpn.J. Vet. Sci. 50(6): 1143-1149, 1988

Oxolinic acid (5-ethyl-5, 8 dihydro-8-oxo1, 3-dioxolo (4, 5-g)-quinoline-7-carboxylic acid: OA) is widely used as an antibacterial agent for veterinary use with calves, pigs, chickens and fish. As OA is orally administered to animals in most cases, the bioavailability after oral administration is thought to be one of the factors affecting its clinical effectiveness. The bioavailability of OA administered in solid dosage form to dogs was reported to be enhanced by reducing the mean particle size [12]. This suggests that its bioavailability in solid dosage form depends on the dissolution rate, not on the absorption rate from solution. Commercial products of OA for veterinary use are thought to have various particle sizes and different bioavailabilities resulting from different dissolution rates. There has been no report on the relationship between dissolution rate and the bioavailability of OA in chickens.
The paper reports the bioavailability of OA administered to chickens in solid dosage forms with different particle sizes under fasting and non-fasting conditions.

\section{MATERIALS AND METHODS}

Preparations: Three preparations of OA used for this study were designated as A, B, and C. A was a suspention of 5.0\% OA, kindly supplied from Tanabe Seiyaku Co., Ltd. (Osaka). B and $\mathrm{C}$ were commercial powders of OA for veterinary use, having purities of $99.9 \%$ and $99.7 \%$, respectively. Particle Size: Mean particle size of OA powders of preparation $\mathrm{A}$ was determined by the sedimentation velocity, and those of preparations $\mathrm{B}$ and $\mathrm{C}$ by microscopy.

Solubility of $O A$ : The solubilities of OA at $\mathrm{pH} 3.6$ and $\mathrm{pH} 7.0$ were determined by the drug concentration in saturated aqueous solutions of $\mathrm{OA}$ after shaking at $37^{\circ} \mathrm{C}$ for 72 
hr. Samples were immediately passed through a membrane filter $(0.45 \mu \mathrm{m})$, and the absorbance of the solution was determined spectrophotometrically at $260 \mathrm{~nm}$ after diluting the filtrate with $0.1 \mathrm{~N}$ sodium hydroxide.

Dissolution Rate: The dissolution rate of $\mathrm{OA}$ at $37^{\circ} \mathrm{C}$ from the preparations was determined by the paddle method (J.P. X). The amounts of OA tested were $4.0 \mathrm{mg}$ at $\mathrm{pH} 7.0$ and $3.0 \mathrm{mg}$ at $\mathrm{pH} 3.6$. The absorbance of the medium sampled at an appropriate time interval was determined at $260 \mathrm{~nm}$ after filtration with a membrane filter $(0.45$ $\mu \mathrm{m})$. The dissolution media $(1000 \mathrm{~m} l)$ containing $0.01 \%$ polysorbate 80 were as follows: $\mathrm{pH} 3.6 ; 0.36 \mathrm{~N} \mathrm{HCl}-0.40 \mathrm{M}$ sodium acetate $(1: 1, \mathrm{v} / \mathrm{v}), \mathrm{pH} 7.0 ; 0.1 \mathrm{M}$ sodium phosphate dibasic $-0.1 \mathrm{M}$ potassium phosphate monobasic $(2: 1, \mathrm{v} / \mathrm{v})$. The stirring rates were $100 \mathrm{rpm}$ and $200 \mathrm{rpm}$.

Bioavailability Tests: Bioavailability test under fasting conditions; fifteen white leghorn chickens (18 to 21 weeks), 9 hens and 6 cocks, weighing 1.0 to $1.5 \mathrm{~kg}$, were initially maintained under the similar conditions for two weeks. The chickens were divided into three groups, to each of which one of the OA preparations was given. A dose of $20 \mathrm{mg} / \mathrm{kg}$ of OA was administered to each chicken with $4 \mathrm{ml}$ of water into the crop through a catheter. The chickens were fasted for $17 \mathrm{hr}$ prior to and $12 \mathrm{hr}$ after oral administration of the preparations. One milliliter of blood was collected from the sub-wing vein at $1,2,3,4,5,6,7,8,10$ and $12 \mathrm{hr}$ after administration. The plasma samples were frozen $\left(-20^{\circ} \mathrm{C}\right)$ until assayed. Effect of food intake on bioavailability of OA; eight white leghorn hens (19 to 23 weeks, 1.25 to $1.5 \mathrm{~kg}$ ) were used. Two preparations, $\mathrm{B}$ and $\mathrm{C}$, were administered to the chickens under fasting and nonfasting conditions by means of a four-way cross-over design with one week intervals between the administrations. For the study of non-fasting conditions the chickens were fed ad libitum with a commercial product for adult chickens (Kyodo Feed Co., Ltd.). For the study of fasting conditions the chickens were fasted for $24 \mathrm{hr}$ prior to and $12 \mathrm{hr}$ after oral administration of the preparations. Other conditions for testing were the same as those for study under fasting conditions.

The pharmacokinetic parameters subjected to statistical analysis (analysis of variance; ANOVA) were peak plasma concentration $\left(\mathrm{C}_{\max }\right)$, time to peak plasma concentration $\left(\mathrm{T}_{\max }\right)$ and area under the plasma concentration - time curve (AUC). Apart from the AUC value, the parameters were observed values. AUC from zero to the last sampling time $\left(\mathrm{AUC}_{0-\mathrm{t}}\right)$ was calculated by the trapezoidal rule. AUC from the last sampling time to infinity was calculated by the following equation:

$$
\mathrm{AUC}_{\mathrm{t}-\infty}=\mathrm{Ct} / \mathrm{Kel}
$$

Where $\mathrm{Ct}$ and Kel are plasma concentration at the last sampling time and the terminal elimination rate constant of $\mathrm{OA}$, respectively. Differences among the preparations were examined by the least significant difference method [16].

Assay: The plasma concentration of OA was determined by high performance liquid chromatography (HPLC) procedure reported previously [8]. To $0.5 \mathrm{~m} l$ of plasma $10 \mathrm{~m} l$ of acetonitrile was added and the mixture was shaken for $10 \mathrm{~min}$. Then $10 \mathrm{~m} l$ of nalidixic acid solution $(0.2 \mu \mathrm{g} / \mathrm{m} l$ in acetonitrile) was added as an internal standard, the solution was filtered using a membrane filter $(0.45 \mu \mathrm{m})$ and evaporated to dryness at $40^{\circ} \mathrm{C}$. The residue was reconstituted with $0.5 \mathrm{~m} l$ methanol, and $20 \mu l$ of the solution was assayed with HPLC. The HPLC system consisted of a column packed with nucleosil $5 \mathrm{C}_{8}(4.6 \mathrm{~mm} \times 250 \mathrm{~mm})$, a detector $(260 \mathrm{~nm})$ and a mobile phase (methanol: acetonitrile: $0.1 \mathrm{M}$ citric acid=6:1:7) with a flow rate of $1.0 \mathrm{~m} / / \mathrm{min}$. 


\section{RESULTS}

As product $A$ is a suspention of $O A$ powders, the mean particle size was found to be $1 \mu \mathrm{m}$ by means of sedimentation velocity. The mean diameters of products $B$ and $\mathrm{C}$ estimated microscopically using the equation, (mean length + mean breadth) $/ 2$, were $5 \mu \mathrm{m}$ and $20 \mu \mathrm{m}$, respectively.

The solubility of $\mathrm{OA}$ at $\mathrm{pH} 3.6$ and $\mathrm{pH} 7.0$ was determined, being considered to be the mean values for the proventriculus and small intestine of the chicken, respectively. Those at $37^{\circ} \mathrm{C}$ were $7.1 \mu \mathrm{g} / \mathrm{ml}$ at $\mathrm{pH} 3.6$ and $13.8 \mu \mathrm{g} / \mathrm{m} l$ at $\mathrm{pH} 7.0$.

Table 1 shows the mean dissolution rates of $\mathrm{OA}$ in products $\mathrm{A}, \mathrm{B}$ and $\mathrm{C}$. The dissolution rate is represented by the times for $30 \%$ dissolution $\left(\mathrm{t}_{30}\right)$ and $50 \%$ dissolution $\left(t_{50}\right)$. The rank order was $A>B>C$ under any conditions. Dissolution rates tended to be faster at $\mathrm{pH} 7.0$ than $\mathrm{pH} 3.6$ in all products, being influenced by $\mathrm{pH}$ on solubility of OA.

Fig. 1 and Table 2 represent the bioavailability of OA after oral administration of products $\mathrm{A}, \mathrm{B}$ and $\mathrm{C}$ to chickens fasted. The results of $\mathrm{AUC}_{0-12}$ and $\mathrm{AUC}_{0-\infty}$ indicated that products $\mathrm{A}$ and $\mathrm{B}$ are bioequivalent in the extent of bioavailability, product $\mathrm{C}$ showing significantly lower bioavailability than $\mathrm{A}$ and $\mathrm{B}$. With respect to mean $\mathrm{AUC}_{0-\infty}$ values, the bioavailability of product $C$ was only one half of that products $A$ and $\mathrm{B}$. The rate of bioavailability according to the $\mathrm{C}_{\max }$ and $\mathrm{T}_{\max }$ also showed large differences among the products. $\mathrm{C}_{\max }$ of product $\mathrm{C}$ was less than $80 \%$ of product $\mathrm{A}$ or $\mathrm{B}$, which means that product $\mathrm{C}$ was inequivalent to the other products in the rate of bioavailability. However, as shown in Table 2, there was no significant difference in $\mathrm{C}_{\max }$ and $\mathrm{T}_{\max }$ among the products, which was ascribed to poor power of statistical analysis, because cross-over study was not used in the bioavailability test.

The effect of food on the bioavailability of OA was studied using commercial products $\mathrm{B}$ and $\mathrm{C}$ which have different bioavailabilities. Fig. 2 shows mean plasma concentration-time curves of OA after oral administration $(20 \mathrm{mg} \mathrm{OA} / \mathrm{kg})$ of products $\mathrm{B}$ and $\mathrm{C}$ under fasting and non-fasting conditions, and Table 3 represents mean values for pharmacokinetic parameters. When OA was adminstered under non-fasting conditions, mean plasma concentrations of $\mathrm{OA}$ in both products were higher until $6 \mathrm{hr}$ after administration, in comparison with those under fasting conditions. Furthermore, $\mathrm{C}_{\max }$ and $\mathrm{AUC}_{0-12}$ values of both products were higher under non-fasting conditions as compared with fasting conditions, while the $\mathrm{T}_{\max }$ values were lower. Product $\mathrm{B}$ administered under non-fasting conditions enhanced remarkably the bioavailability of $\mathrm{OA}$, product $\mathrm{C}$ showing less enhancement. Then, the difference in bioavailability of these products was increased when administered under non-fasting conditions.

Table 1. Dissolution rates of oxolinic acid from three preparations determined by the paddle method (J.P.X)

\begin{tabular}{|c|c|c|c|c|c|c|}
\hline \multirow{3}{*}{ Condition } & \multicolumn{6}{|c|}{ Dissolution rate } \\
\hline & \multicolumn{3}{|c|}{$\mathrm{t}_{30}$} & \multicolumn{3}{|c|}{$\mathrm{t}_{50}$} \\
\hline & A & $\mathrm{B}$ & $\mathrm{C}$ & A & B & $\mathrm{C}$ \\
\hline $\mathrm{pH} 7.0,100 \mathrm{rpm}$ & $6 \mathrm{sec}$ & $3 \mathrm{~min}$ & $27 \mathrm{~min}$ & $11 \mathrm{sec}$ & $21 \mathrm{~min}$ & $52 \mathrm{~min}$ \\
\hline $\mathrm{pH} 7.0,200 \mathrm{rpm}$ & $11 \mathrm{sec}$ & $3 \mathrm{~min}$ & $18 \mathrm{~min}$ & $14 \mathrm{sec}$ & $8 \mathrm{~min}$ & $40 \mathrm{~min}$ \\
\hline pH $3.6,100 \mathrm{rpm}$ & $25 \mathrm{sec}$ & $11 \mathrm{~min}$ & $32 \mathrm{~min}$ & $33 \mathrm{sec}$ & 2: $\min$ & $74 \mathrm{~min}$ \\
\hline
\end{tabular}




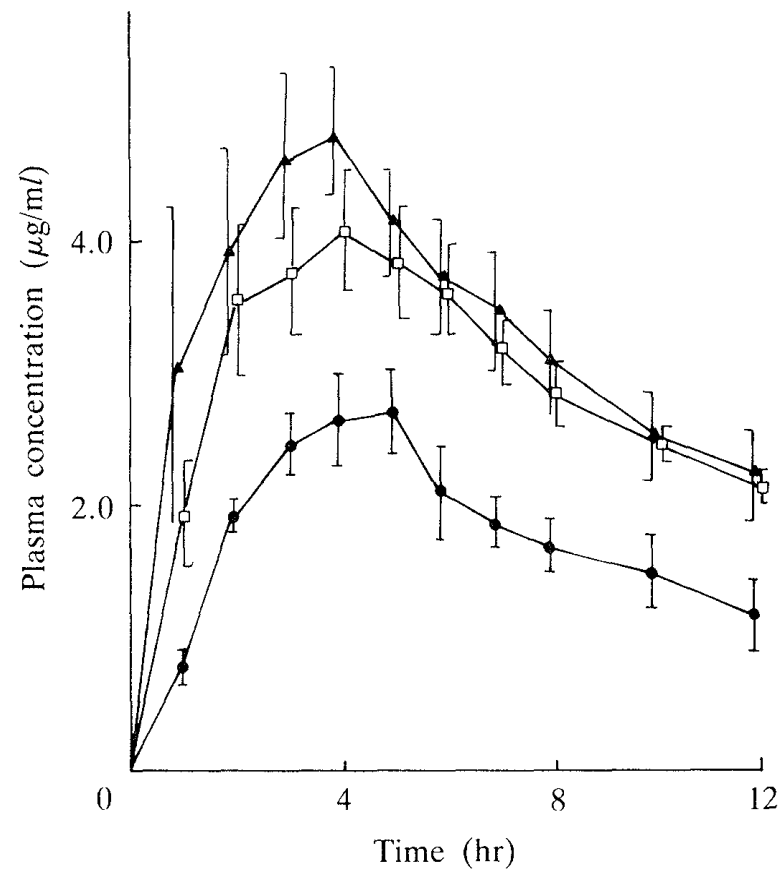

Fig. 1. Mean plasma oxolinic acid concentration after oral administration of oxolinic acid preparations to 5 chickens $(20 \mathrm{mg}$ of $\mathrm{OA} / \mathrm{kg}$ ) fasted. Each point and vertical bar represent mean $\pm S$.E. $(\square-\square)$ product $\mathrm{A}$; $(\mathbf{A}-\mathbf{\Delta})$ product $\mathrm{B}$; product $\mathrm{C}$.

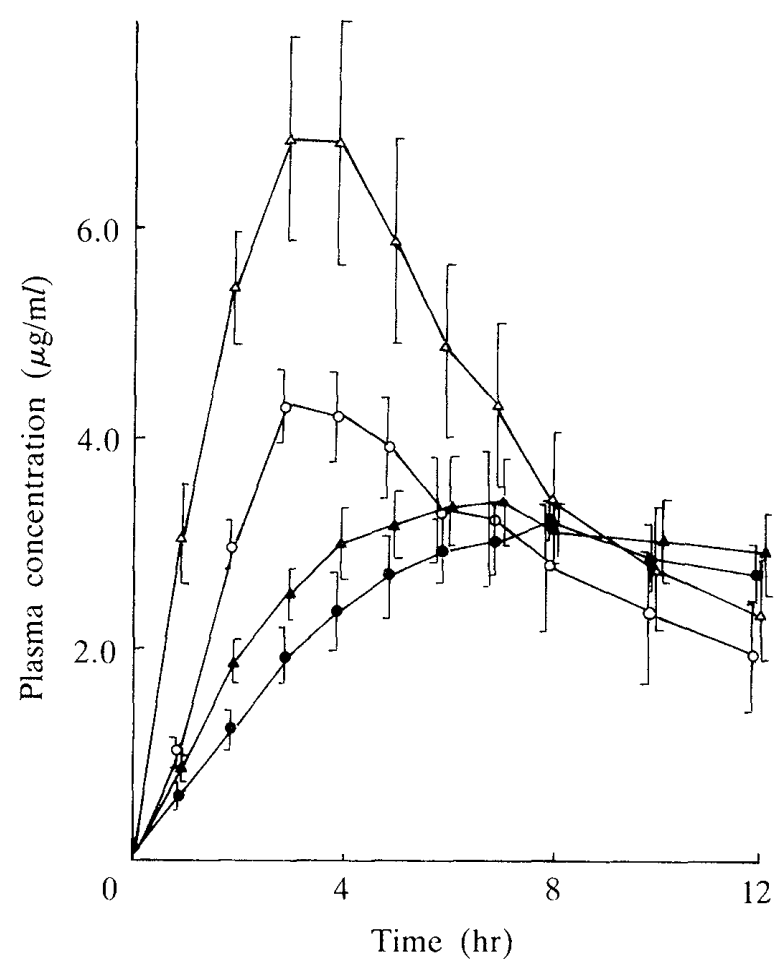

Fig. 2. Mean plasma concentration of oxolinic acid after oral administration of oxolinic acid preparations to 8 chickens under fasting conditions and non-fasting conditions by means of a cross-over study. Each point and vertical bar represent mean \pm S.E. $(\triangle-\triangle)$ product $B$ in non-fasting conditions; $(\mathrm{O}-\mathrm{O})$ product $\mathrm{C}$ in non-fasting conditions; $(\boldsymbol{\Delta}-\mathbf{A})$ product $\mathrm{B}$ in fasting conditions; $(-)$ product $\mathrm{C}$ in fasting conditions.

Table 2. Bioavailability parameters of oxolinic acid after oral administration of three preparations $(20 \mathrm{mg}$ of $\mathrm{OA} / \mathrm{kg}$ ) to chickens under fasting condition

\begin{tabular}{lcccc}
\hline & $\begin{array}{c}\mathrm{C}_{\max }^{\mathrm{a})} \\
(\mu \mathrm{g} / \mathrm{m} l)\end{array}$ & $\begin{array}{c}\mathrm{T}_{\max }^{\mathrm{a})} \\
(\mathrm{hr})\end{array}$ & $\begin{array}{c}\left.\mathrm{AUC}_{0-12}^{\mathrm{a}}\right) \\
(\mu \mathrm{g} \cdot \mathrm{hr} / \mathrm{m} l)\end{array}$ & $\begin{array}{c}\left.\mathrm{AUC}_{(-\infty}^{\mathrm{a}}\right) \\
(\mu \mathrm{g} \cdot \mathrm{hr} / \mathrm{m} l)\end{array}$ \\
\hline Preparation A & $4.3 \pm 0.52$ & $3.0 \pm 0.45$ & $35.7 \pm 3.47$ & $57.7 \pm 3.53$ \\
Preparation B & $5.1 \pm 0.71$ & $3.4 \pm 0.60$ & $39.9 \pm 4.85$ & $67.9 \pm 13.28$ \\
Preparation C & $2.9 \pm 0.36$ & $4.4 \pm 0.40$ & $21.5 \pm 2.46$ & $27.5 \pm 4.43$ \\
ANOVA & $\mathrm{NS}^{\mathrm{b})}$ & $\mathrm{NS}^{\mathrm{b})}$ & $\mathrm{P}<0.025$ & $\mathrm{P}<0.025$ \\
Multiple range test & & & $\underline{\mathrm{B}>\mathrm{A}>\mathrm{C}}$ & $\underline{\mathrm{B}>\mathrm{A}>\mathrm{C}}$ \\
\hline
\end{tabular}

a) The figures indicate means \pm standard errors.

b) NS; not significant ( $\mathrm{p}>0.05$ ).

c) Preparations underlined by a common line did not differ significantly $(\mathrm{p}>0.05)$.

\section{DISCUSSION}

OA is a weak acid drug with a pKa of 6.88 , showing very low solubility $(7.1 \mu \mathrm{g} / \mathrm{m} l$ at $\mathrm{pH} 3.6$ and $13.8 \mu \mathrm{g} / \mathrm{ml}$ at $\mathrm{pH} 7)$. In the studies on humans and dogs, indomethacin (weak acid drug; solubility of $16 \mu \mathrm{g} / \mathrm{ml}$ at pH 3 and $1.9 \mathrm{mg} / \mathrm{ml}$ at $\mathrm{pH}$ 7.2) [2], nalidixic 
Table 3. Bioavailability parameters of oxolinic acid after oral administration of oxolinic acid preparations $(20 \mathrm{mg}$ of $\mathrm{OA} / \mathrm{kg}$ ) to chikens under fasting and non-fasting conditions

\begin{tabular}{lccc}
\hline & $\mathrm{C}_{\max }^{\mathrm{a})}(\mu \mathrm{g} / \mathrm{m} l)$ & $\mathrm{T}_{\max }^{\mathrm{a})}(\mathrm{hr})$ & $\begin{array}{c}\left.\mathrm{AUC}_{0-12}^{\mathrm{a}}\right) \\
(\mu \mathrm{g} \cdot \mathrm{hr} / \mathrm{m} l)\end{array}$ \\
\hline $\begin{array}{l}\text { Non-fasting } \\
\text { Preparation B(B) }\end{array}$ & $7.3 \pm 1.22$ & $3.6 \pm 0.32$ & $50.2 \pm 7.95$ \\
$\begin{array}{l}\text { Non-fasting } \\
\text { Preparation C(C) }\end{array}$ & $4.7 \pm 0.44$ & $4.3 \pm 0.62$ & $33.9 \pm 5.10$ \\
$\begin{array}{l}\text { Fasting } \\
\text { Preparation B(b) }\end{array}$ & $3.8 \pm 0.40$ & $7.6 \pm 1.05$ & $31.9 \pm 3.21$ \\
$\begin{array}{l}\text { Fasting } \\
\text { Preparation C(c) }\end{array}$ & $3.6 \pm 0.35$ & $7.3 \pm 0.86$ & $28.2 \pm 2.17$ \\
$\begin{array}{l}\text { ANOVA } \\
\text { Multiple range test }{ }^{\mathrm{b})}\end{array}$ & $\mathrm{p}>0.01$ & $\mathrm{P}<0.01$ & $\mathrm{p}<0.01$ \\
\hline
\end{tabular}

a) The figures indicate means \pm standard errors.

b) Preparations underlined by a common line did not differ significantly $(\mathrm{p}>0.05)$.

acid (weak acid drug; solubility of $38 \mu \mathrm{g} / \mathrm{m} l$ at $\mathrm{pH} 3.1$ and $446 \mu \mathrm{g} / \mathrm{m} l$ at $\mathrm{pH} 7.0)$ [14] and griseofulvin (neutral drug; solubility of 32 $\mu \mathrm{g} / \mathrm{ml}$ at $\mathrm{pH}$ 7.2)[3] show different bioavailabilities among their commercial products. This has been reported to be caused by differences in dissolution rates among the dosage forms. The Food and Drug Administration has also reported that a drug whose solubility is less than $5 \mathrm{mg} / \mathrm{ml}$, has a dissolution rate-dependent bioavailability in humans [7]. The bioavailability of OA has been shown to depend on particle size of the powder applied in the dog [12]. These suggest that absorption of OA may depend on a dissolution rate in the solid dosage form.

Powder products of OA for veterinary use ( $B$ and $C$ ) were found to have different mean particle sizes. Product A consists of ultramicronized powders [9-11]. Dissolution rates of $\mathrm{OA}$ in the products varied in proportion to the mean particle sizes. The dissolution rate of $\mathrm{OA}$ might also be affected by crystral form, but the powder $\mathrm{X}$-ray diffraction patterns of products $\mathrm{A}, \mathrm{B}$ and $\mathrm{C}$ showed no difference in crystal form (the data were not shown). Therefore, the large differences in dissolution rates among the products can be reasonably ascribed to differences in mean particle sizes.

It is curious that the bioavailabilities of OA were almost the same between products $A$ and $B$ (Table 2 and Fig. 1), although product $A$ showed very fast dissolution rate of $\mathrm{OA}$ in comparison with product $\mathrm{B}$ (Table 1 ). This discrepancy may be due to the following lines of speculation.

First, the bioavailability of OA in product A may depend on the absorption rate of OA itself, not on the dissolution rate of the product, because the dissolution rate is very fast. However, the speculation seems to be hardly possible because the extent of OA bioavailability was enhanced under nonfasting conditions (Table 3 and Fig. 2).

Secondly, the bioavailability of $\mathrm{OA}$ in product A may depend on the solubility of $\mathrm{OA}$ in the gastrointestinal fluids. OA may be saturated easily in the gastrointestinal fluid because of its very low solubility and the presumptive small volume of the fluids.

The bioavailability of OA in both products ( $B$ and $C$ ) was enhanced by food intake in chickens. Enhanced bioavailability induced by food intake is often observed in 
humans, especially when a drug with very low solubility is administered. This is ascribed to the solubilization of drugs by bile salts excreted stimulatively after food intake or to the prolongation of absorption time due to delayed gastric emptying time $[1,4-6]$.

In humans, food intake often reduces differences in bioavailabilities among drug preparations observed under fasting conditions, due to enhanced bioavailability of the preparations, especially those with poor bioavailability $[1,13, .15]$. In chicken, however, the difference in bioavailabilities between the products was increased by food intake.

For the explanation of the food effect on bioavailability of OA, there are two possible hypotheses. One is that the bioavailability of OA under fasting conditions is determined by the very low amount of OA dissolved in the gastrointestinal fluid due to the very low solubility of OA and small volume of fluid; this leads to a very slow and long absorption without any difference between the products. Under non-fasting conditions, the dissolution rate would determine the bioavailability because of the increased amount of OA dissolved, which produces enhanced bioavailability and greater differences among bioavailabilities. The other hypothesis is that OA bioavailability is determined by the presumed slow rate of gastric emptying of $\mathrm{OA}$ powders under fasting conditions, which diminishes the difference of the bioavailabilities between products. If gastric emptying is accelerated by food intake, most of the powders would be delivered into the small intestine rapidly, followed by particle size-dependent dissolution and the resulting bioavailability. As there are few data for gastric emptying in chickens, the latter hypothesis is more speculative.

In conclusion, it is suggested that the bioavailability of OA under fasting condi- tions depends on the dissolution rate when the product has a mean OA particle size of more than $5 \mu \mathrm{m}$. The bioavailability of OA may be not changed when the mean particle size of OA is prepared to be less than $5 \mu \mathrm{m}$, probably because bioavailability is determined by absorption rate from the gastrointestinal fluid or by solubility in the fluid in this situation. Under non-fasting conditions, the extent of bioavailability of OA was largely enhanced in addition to the rate of the bioavailability, and the bioavailability seemed to more depend on the dissolution rate in comparison with that under fasting conditions.

ACKNowledgements. We thank Dr. E. Suzuki, Kitasato University, for her cooperation. Authentic drugs are graciously provided by Tanabe Seiyaku and Sankyo Zoki.

REFERENCES

1. Aoyagi, N., Ogata, H., Kaniwa, N., and Ejima, A. 1982. Effect of food on the bioavailability of griseofulvin from microsize and PEG ultramicrosize (Gris-PEG) plain tablets. J. Pharm. Dyn. 4: 120-124.

2. Aoyagi, N., Ogata, H., Kaniwa, N., and Ejima, A. 1985. Bioavailability of indomethacin capsules in humans (1): bioavailability and effects of gastric acidity. Int. J. Clin. Pharmacol. Ther. Toxicol. 23: 469-474.

3. Aoyagi, N., Ogata, H., Koibuchi, M., Shibazaki, T., and Ejima, A. 1982. Bioavailability of griseofulvin from tablets in humans and the correlation with its dissolution rate. J. Pharm. Sci. 74: 1165-1169.

4. Bates, T. R., Sequeira, M. S., and Tembo, B. S. 1974. Effect of food on nitrofurantoin absorption. Clin. Pharmacol. Ther. 16: 63-68.

5. Beermann, B., and Groschinsky-Grind, M. 1978. Gastrointestinal absorption of hydrochlorothiazide enhanced by concomitant intake of food. Eur. J. Clin. Pharmacol. 13: 125-128.

6. Crounse, R. G. 1963. Effective use of griseofulvin. Arch. Dermatol. 87: 176-180.

7. Federal Register. 1977. 42FR1648, January 7.

8. Hamamoto, K. 1986. Rapid high-performance liquid chromatographic method for the determination of oxolinic acid in chicken plasma. $J$. Chromatogr. Biomedical Applications. 381: $453-456$. 
9. Hirakawa, Y., and Harada, K. 1982. Studies on development of the ultrafine size reduction method of slightly soluble medicinal crystals. I. Evaluation of size reduction effect for oxolinic acid by the polycarbonate membrane filtration. Yakugaku Zasshi. 102: 951-959 (in Japanese).

10. Hirakawa, Y., and Harada, K. 1983. Studies on development of the ultra-fine size reduction method of slightly soluble medicinal crystals. II. Various factors affectng the ultra-fine size reduction of oxolinic acid crystal. Yakugaku Zasshi. 103: 690-695 (in Japanese).

11. Hirakawa, Y., and Harada, K. 1983. Studies on development of the ultra-fine size reduction method of slightly soluble medicinal crystals. III. The inference of origin for ultra-fine size reduction of oxolinic acid crystal. Yakugaku Zasshi. 103: 1215-1218 (in Japanese).

12. Hirakawa, Y., and Harada, K. 1983. Studies on development of the ultra-fine size reduction method of slightly soluble medicinal crystals. IV.
Enhanced bioavailability of oxolinic acid by Ultra-fine size reduction. Yakugaku Zasshi. 103: 1190-1194 (in Japanese).

13. Ogata, H., Aoyagi, N., Kaniwa, N., and Ejima, A. 1984. Effect of food on bioavailability of nalidixic acid from uncoated tablets having different dissolution rates. J. Pharm. Dyn. 7: 760-767.

14. Ogata, H., Aoyagi, N., Kaniwa, N., Shibazaki, T., Ejima, A., Takasugi, N., Mafune, E., Hayashi, T., and Suwa, K. 1984. Bioavailability of nalidixic acid from uncoated tablets in humans. Part I: Correlation with the dissolution rates of the tablets. Int. J. Clin. Pharmacol. Ther. Toxicol. 22: 175-183.

15. Ogata, H., Shibazaki, T., Inoue, T., and Ejima, A. 1979. Dissolution systems for chloramphenicol tablet bioavailability. J. Pharm. Sci. 68: 712-715.

16. Okubo, C., and Haga, Y. 1969. The new statistics series. Experimental design. Baifukan, Tokyo (in Japanese).

要約

絶食および採食状態の鶏におけるオキソリン酸のバイオアベイラビリティーとその溶出率：浜本好子・緒方宏

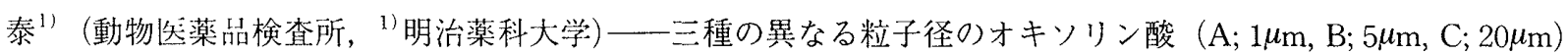
を鶏に $20 \mathrm{mg} / \mathrm{kg}$ 経口投与し，そのバイオアベイラビリティー（BA）を絶食あるいは採食状態において測定，比 較した。オキソリン酸の溶出率は，その粒子径の違いにより大きな差異を示した。絶食状態では，AおよびB のBAはCより有意に良好であったが，AとBの間には差はみられなかった。 BとCのBAは，絶食状態に比 較して採食状態の犺有意に良好で，絶食時に見られたBAの差は採食時に，より顕著になった。

この結果より，才キソリン酸の BA は $5 \mu \mathrm{m}$ より大きな粒子径を持つ製剤においては，溶出速度に依存するが， $5 \mu \mathrm{m}$ 以下の製剤では，それに依存しないことが示唆された。 